\title{
The allure of art and intellectual property: Artisans and industrial replicas in Mexican cultural economies
}

Article

Accepted Version

Cant, A. (2015) The allure of art and intellectual property: Artisans and industrial replicas in Mexican cultural economies. Journal of the Royal Anthropological Institute, 21 (4). pp. 820837. ISSN 1359-0987 doi: https://doi.org/10.1111/14679655.12289 Available at https://centaur.reading.ac.uk/86150/

It is advisable to refer to the publisher's version if you intend to cite from the work. See Guidance on citing.

To link to this article DOI: http://dx.doi.org/10.1111/1467-9655.12289

Publisher: Wiley

All outputs in CentAUR are protected by Intellectual Property Rights law, including copyright law. Copyright and IPR is retained by the creators or other copyright holders. Terms and conditions for use of this material are defined in the End User Agreement.

www.reading.ac.uk/centaur 
Central Archive at the University of Reading

Reading's research outputs online 
Cant, Alanna. 2015. 'The Allure of Art and Intellectual Property: Artisans and industrial replicas in Mexican cultural economies.' Journal of the Royal Anthropological Institute 21(4): 820-837.

\begin{abstract}
This article considers the establishment of a collective trademark by Mexican artisans which occurred in response to the discovery of industrial replicas of Oaxacan woodcarvings, and it suggests that artisans' appeals to intellectual property cannot be readily understood as resulting from the economic or cultural threat that the replicas ostensibly pose. By bringing an analysis of aesthetics and the desirability of art into anthropological discussions of intellectual property, I argue that intellectual property is appealing to cultural producers in such contexts because it seems to offer an opportunity to stabilize the ambiguities concerning the relationship between authorship and the allure of artworks within competitive cultural markets. I conclude that in this case, claims to intellectual property reveal concerns that are more about local practices than about foreign production.
\end{abstract}

At the height of Oaxaca's Day of the Dead celebrations in 2007, the Las Noticias newspaper ran a story much like the Mexican peasant folktales that anthropologists have been collecting there for generations: a year earlier, a foreigner had come to the small villages surrounding the city and proposed a deal that would make people money well beyond their expectations. The stranger, who was only identified as 'El Americano,' had purchased five large Oaxacan woodcarvings, and in exchange for a signature on a contract, paid their producers significantly more than their usual asking prices. When El Americano returned in 2007 to buy more pieces, the artisans and the reading public were horrified to discover that he had taken the carvings to China to have them made into resin replicas, or as the newspaper put it, 'clones,' which were 
now being sold in the United States and online. While the Mexican folktales usually end with the stranger - that is, the Devil - tricking the local protagonist and leaving him with less than he began with, the newspaper story suggested that something must be done. ${ }^{1}$

The story broke as part of an ongoing campaign by Oaxacan state officials to inform residents that their culture and economy were at risk from cheap consumer goods and 'pirated' Oaxacan products from China and Central America that were flooding local marketplaces. While there had been concerns about Guatemalan textiles in Oaxacan markets for some time, this was the first known incident of Oaxacan woodcarvings being transformed into illicit replicas. In response, artisans from the prominent woodcarving communities of San Martín Tilcajete and San Antonio Arrazola requested assistance from ARIPO, the Oaxacan Craft Institute. ${ }^{2}$ At ARIPO's suggestion, the artisans decided to form a collective trademark union to protect their work from imitations. With organizational and financial support from Oaxacan and federal state agencies, artisans established their collective trademark in April 2008 under the name 'The Union of Woodcarvers, Producers of Alebrijes, Tonas of Oaxaca'.

Some weeks after its founding, I was discussing the collective trademark over coffee with Antonio Mendoza Ruíz, a member of a well-known weaving family and an active participant in Oaxaca City's vibrant artistic community. As I described the resin copies and the artisans' trademark, he stopped me: 'But what I don't understand is why do they care?' he asked. To my surprise, I found myself unable to answer this question. It seemed self-evident that artisans would condemn replicas of their work; as the newspaper story suggested, their creative expressions had been copied and sold en masse, not only putting their livelihoods at risk but also committing the morally charged offence of 'cultural appropriation,' an 
accusation central to many current disputes involving indigenous and minority groups today (Coombe 1998; Coleman 2004; Geismar 2005; Tan 2013). However, as I thought about Antonio's question, I realized that these particular factory copies, made in China and trademarked as 'InSpiriters,' actually posed little or no threat to local livelihoods, nor could they be accused of simply appropriating culture. After a moment or two, I had to admit that I was not entirely sure.

Antonio's unexpected question lingered in my mind as I continued my ethnographic research with artisans in San Martín Tilcajete, where I worked for twenty months in 2008 and 2009. Located 40 kilometres south of Oaxaca's state capital, San Martín is one of three main villages where Oaxacan woodcarvings or 'alebrijes' are produced and sold to tourists, wholesalers and collectors of Mexican folk art. ${ }^{3}$ While my research participants were sincerely concerned about the industrial replication of their work, Antonio's question forces us to consider what else claims to intellectual property might be doing in Oaxaca. Rather than reposing on generalized economic or culturalist explanations of artisans' appeals for intellectual property protection, I suggest that they must be understood within a broader consideration of artisans' own experiences within the ethnic art and craft markets in which their work circulates.

Oaxacan woodcarvers find themselves working at the intersections of various material and social categories currently at play in southern Mexico. These categories - such as 'art', 'craft', 'Mexican', and 'indigenous' - structure the markets and cultural discourses that drive the circulation of their work throughout Mexico and North America more generally. Like other cultural producers around the world, the artisans' perspectives are of course coloured by 
such discourses that legitimate them as the makers and bearers of authentic local and national culture. At the same time, they increasingly work within social and economic conditions that encourage principles of market rationality, individual rights and personalized success. The everyday blending of these ideologies - of 'extraordinary authentic culture' and 'commonsense entrepreneurship' - underwrites contemporary forms of neoliberal multiculturalism that characterize current relations between states, citizens and markets around the world (Gershon 2011; Hale 2005).

The work of such markets and institutions does more than simply bringing cultural and commodity forms into coexistence. Neoliberal multiculturalism profoundly transforms the relationship between people and their cultural identities by recasting groups and individuals as the owners of culture and so annexes liberal concepts of property and rights into lived cultural practices, all the while producing economic value at the boundaries of cultural difference (Comaroff and Comaroff 2009; Coombe 1998; Gershon 2011:539-543). This cultural propertization has taken place in tandem with the extension, both industrially and geographically, of intellectual property (IP) law, which has become a powerful tool that states and international institutions promote to regulate the increasingly lucrative immaterial aspects of capitalist production. Through IP, the intellectual or creative elements of products are legally separated from their material forms, creating new possibilities for ownership and the production of value (May 2010: 49-58).

This separation has also been productive for anthropologists. Cori Hayden (2003), James Leach (2008), and Marilyn Strathern (1999), amongst others, have used IP to interrogate how different understandings of property mediate the social and material relations 
that surround them. Conversely, others have focused on how technologies of mass reproduction and distribution have led to a proliferation of replica consumer goods that push both IP and local engagement with 'originals' and 'fakes' in novel directions (Newell 2013; Thomas 2013). In Latin America in particular, scholars have explored the intimate relations between 'piracy' and the production of illegality, interrogating how IP reconfigures citizenship, subjectivities and morality under the unstable conditions of the region's neoliberalizing states (see Dent 2013). IP often becomes a tool through which heavy-handed states use neoliberalist frameworks to further assert control, whether in the context of 'wars on piracy' or the formalization of hitherto informal, but lucrative, economic relations (Aguiar 2013; Bowen and Gaytán 2012; Thomas 2013).

IP's advancement has also challenged anthropologists who work with artists and craftspeople, as it actively produces regimes of authorship which may or may not accord with local understandings or practices (Aragon 2011; 2014; Brown 2003; Geismar 2005). As I will discuss below, the authorship concept as enshrined in IP presumes a clear relationship between a recognizable author and the products that they create, which forms the foundation of the author's rights in those products. This presumption engages core debates within the anthropology of art, in particular the recognition and production of authenticity, which is itself a discourse about legitimate versus illegitimate production. As authenticity and its related forms of value are increasingly marked by legal recognitions of IP, it now has real consequences for all artistic producers, including those who do not directly engage with it (Myers 2005). 
As such, anthropologists can be said to approach IP as an analytical "place of condensation,' a term used by Jesús Martín-Barbero to visualize the Latin American culture industries as complex spaces where legal, technological, mercantile and political processes are tightly entwined; 'condensing' their individual features into a consequential aggregate and making visible their collective synergies (2000: 28). Likewise, within anthropology, IP has become a conceptual space in which the collusive logics of property, nationalism, capitalism and neoliberalism more generally are analytically connected and can be rendered visible (cf. Hirsch 2010). The expansion of IP thus offers anthropologists a useful lens through which the subtleties of artistic economic life can be refracted and teased apart, while at the same time producing new puzzles and predicaments within cultural economies.

Indeed, one key element for understanding the artisans' strong reactions to the discovery of the industrial replicas is common to economies of culture: the intense competition within Oaxaca's craft markets has created new and marked hierarchies among producers of ostensibly traditional material culture. As I will discuss below, in San Martín Tilcajete these hierarchies are largely due to unequal access to knowledge about what different kinds of consumers think Oaxacan woodcarvings should look like. The most successful artisans, Miguel and Catalina García, have deliberately cultivated their work to appeal to these perspectives, while other artisans are unable to make the same aesthetic moves. I will suggest that the appearance of the industrial replicas threatened an already unstable matrix of cultural expression, by hinting that foreigners may be able to replicate the appeal of successful Oaxacan artisans' work. ${ }^{4}$ From this point of departure, my central argument - and indeed, my answer to Antonio - proceeds along two interconnecting paths: 
First, drawing on theoretical perspectives elaborated by Walter Benjamin and Mario Biagioli, I argue that the InSpiriter replicas provoked anxieties for artisans not because their rights were violated per se, but because they called into question the anticipated relationship between authorship and the desirability of works of art. In an unpredictable economy in which aesthetic authority seems unevenly distributed among local producers, the collective trademark's allusion to shared identity and authorship chiefly references anxieties within the community about the desirability of Oaxacan woodcarvings. As I will show, the ways in which Oaxacan artisans position their work in order to enhance its appeal are complex and diverse. Rather than concentrating on how these practices relate to touristic configurations of authenticity, I argue that desirability must be understood in relation to the authority of the woodcarvings as art objects, which can be theorized via Benjamin's concept of the 'aura' of works of art. Benjamin's aura is a useful device here because it points both to the enigmatic allure of artworks and how this allure is intimately connected to the viewer's own understanding of the art object. This is particularly useful in San Martín, because consumers of Oaxacan woodcarvings are by no means a homogenous group; while some see the carvings as characteristic of Mexican popular culture, others read them as Native American art, while others still are more interested in how the carvings may represent their own personal experiences or attributes.

Second, I argue that anxieties about industrial replicas reflect and heighten ambivalent positions within globalized art worlds, and that the artisans turned to intellectual property in order to clarify the artistic and economic processes that they work within when making and marketing Oaxacan woodcarvings. I suggest that like anthropologists, artisans also view IP as a 'place of condensation' that may help to illuminate uncertain relations and possibly offer solutions to larger issues than the specific case at hand. What the paper more largely suggests, 
then, is that an answer to Antonio's question of 'why do they care?' provides an illuminating explanation of how hierarchies and uncertainties are formed and negotiated within artproducing communities. Connecting these processes to aesthetic practices and the enduring allure of art, my analysis also suggests that the agentic qualities of art and craft objects themselves offer ways of conceptualising popular engagements with discourses of intellectual property.

\section{Oaxacan Woodcarvings in Mexico's Economies of Culture}

For the Mexican and foreign tourists who visit workshops on day trips from Oaxaca City, San Martín Tilcajete is a sleepy, picturesque town nestled amongst neatly tended fields of maize and squash, under a dramatic high desert ridge that shelters it from the bustle and noise of Oaxaca City in the valley below. As they travel along the village's straight, dusty streets, tourists are more likely to encounter young men herding goats or small children in school uniforms than they are other visitors, casting the village and its inhabitants in a glow of everyday authenticity. The workshops where Oaxacan woodcarvings are made generally reinforce this impression - located in the shady courtyards or cool front rooms of artisans' homes, tourists are told that family members produce their pieces together, using natural talents and traditional inclinations to make the bright and imaginative carvings that embody the colourful folk culture of rural Mexico. This vision of San Martín fits neatly into the dominant discourses about craftwork that shape the economies of culture in which Oaxacan woodcarvings and other handicrafts circulate: Mexican discourses that tie artisanal work to the production of the nation, and touristic discourses that frame village-based craftwork as traditional cultural practice. 
As many authors have described, artisans and their products played a highly visible role in Mexico throughout the twentieth century. Following the end of the Revolution in 1920, the federal state and intelligentsia in Mexico City symbolically positioned artesanías (craftwork) at the heart of the nationalist project, while simultaneously viewing it as a means to extend economic development to the impoverished countryside (García Canclini 1993; López 2010; Novelo 1976). This project was pursued through the aegis of federal cultural and 'indigenista' institutions like the National Institute of Anthropology and History and the National Indigenist Institute (García Canclini 1995: 118-120; López 2010: 68-125). Since the 1990s, globalization and the expansion of neoliberalism in Mexico have reconfigured, although certainly not diminished, the valorization of artesanías. Federal agencies like the National Fund for the Development of Artesanías (FONART) and the Secretary for Tourism work with state-level bureaus and private industry to promote craftwork as an important resource in the tourism sector and as an alternative to migration for rural peoples. Perhaps paradoxically, artesanías' continuing symbolism of Mexico's distinctiveness against what is imagined as globalization's push towards homogenization furnishes the contemporary neoliberalizing state with an abundance of cultural resources through which it can control and commoditize cultural discourses by recasting them in the globalized language of heritage and patrimony (García Canclini 2014; Scher 2010; Villaseñor Alonso and Zolla Márquez 2012).

From the perspective of these national-level processes, the state of Oaxaca is a key site where artesanías and their attending visions of history, authenticity, and tradition have been produced and circulated (Alonso 2004: 469; Brulotte 2012; Wood 2008). Until the 1980s, its economy was primarily based on peasant agriculture, vernacular artisanal production and primary resource extraction. Over the past thirty years, service sector employment has grown dramatically following governmental attention to tourism development, now one of Oaxaca's 
main economic drivers and a major concern for the state and its increasingly tourismdependent communities (Murphy and Stepik 1991: 85-87; Stephen 2013: 178-208). Apart from a few small beach resorts on the Pacific, Oaxaca is primarily a destination for cultural tourism, focused on three major themes: pre-Hispanic archaeological sites and artefacts; colonial architecture; and the food and culture of 'traditional' and indigenous peoples (Lira Vásquez 2009; Wood 2008: 31-52). As Oaxaca is the location of two UNESCO world heritage sites and more than 3000 others legally registered as national patrimony through the National Institute of Anthropology and History, its tourism development is intimately linked to the 'heritagization' of Mexican history and culture by the neoliberal multiculturalist state (cf. Breglia 2006).

Set within these ideological frames of reference, the villages where textiles, pottery and woodcarvings are produced become both sources of cultural commodities and tourist destinations in themselves. Through performances by merchants in shops and marketplaces, and by artisans in their own workshops, Oaxacan woodcarvings are constructed as traditional, authentic and quintessentially Mexican material culture, and therefore also indexes of local identity (cf. Little 2004: 102-141; 203-226; Wood 2008: 105-114). However, the history of Oaxacan woodcarvings is much shorter than the term 'tradition' normally implies. In the 1950s Manuel Jiménez, a sometime-mason and peasant farmer from the village of Arrazola, began selling carved masks and small sculptures to vendors in Oaxaca City's market. With investment and guidance from two craft dealers, by the 1960s Jiménez had developed a style of carving whose chief inspirations were Mexican folktales and other traditional crafts. Seeking to capitalize on this new trade, his neighbours began to produce pieces of varying quality and price for the wholesale and tourist market. ${ }^{5}$ Woodcarvings only began to be produced in San Martín Tilcajete in the 1970s, when the newly-established FONART 
encouraged local production through purchasing schemes and woodcarving competitions (Chibnik 2003: 19-30). This coincided with larger state programmes aimed at integrating rural areas into national development plans, and FONART took a leading role in the organization of artesanía markets throughout the country (López 2010: 190-193).

Since this history seemed to conflict with nationalist visions of artesanías' authenticity, FONART and ARIPO were initially hesitant in their support for this new genre of Mexican craftwork (Chibnik 2003:10). However, state agencies have ultimately incorporated the woodcarvings into their representations of local culture, repositioning them as symbols of Oaxaca and encouraging artisans to regard themselves as authentic producers and guardians of 'Oaxacanness'. As nationalist and touristic discourses in Oaxaca now frame the woodcarvings in terms of authenticity and tradition, their desirability appears to be directly linked to their production by hand in family workshops in small, picturesque villages with ostensibly traditional forms of life. From this perspective, all the woodcarvings that are produced in San Martín should, in principle, have the same ability to satisfy touristic desires for the 'really real' (Handler and Saxton 1988; Little 2008: 203-226).

Yet, while most of the artisans are aware of this perception, both the woodcarvings' history and their own uneven successes seem to call these readings of desirability into question. While 68 percent of San Martín's households participate in woodcarving production, only a few families have become financially secure. ${ }^{6}$ Their successes are particularly visible to their neighbours, as their relative wealth materializes in vehicles, home improvements and new businesses, such as restaurants along the highway. The emergence of these new inequalities is particularly troubling for villagers; many told me that they were detrimental to 
the village's character and ethos since San Martín Tilcajete is institutionalized as an egalitarian community. The village holds communal titles to its agricultural land and is an autonomous municipality under Oaxaca's usos y costumbres system, in which governance is managed through 'traditional rule' where all adult males accrue authority within the civil hierarchy through service to the community. ${ }^{7}$ New tensions of competition within increasingly saturated and unpredictable markets challenge the ideals of communalism that many villagers see as foundational to their community's identity and cohesion.

After fifteen years of working together, Miguel and Catalina García are now the most successful family in San Martín, both economically and in terms of their renown. While touristic discourses suggest that Oaxacan artisans produce their carvings through traditional and communal aesthetic sensibilities, the Garcías have intentionally positioned themselves at the aesthetic and ideological intersections of tourism and the ethnic art world, which is populated by Mexican and American museum staff, gallery owners, folk art collectors, and dealers. While this art world recognizes that culture and tradition play a role in woodcarving practices, they also understand the pieces to be the products of creative individuals. Thus, in addition to cultural authenticity, a significant indicator of the woodcarvings' value from this perspective is authorship, or the individual artisan's name and reputation (cf. Steiner 1995: 137). Indeed, in Oaxacan woodcarving, like other Mexican artesanías, the development of un nombre ('a name for one's self') is crucial for success, as clients are more likely to seek out work by known carvers, and artisans must build up documented histories of their participation in competitions in order to secure invitations from galleries and visas to travel to shows in the United States. 
Many artisans in San Martín have become accustomed to working in both the registers of cultural tourism and the ethnic art world. Depending on context and the people with whom they are speaking, individuals will describe their work as 'traditional culture' or 'individual creativity.' While this situation allows artisans to position themselves in creative ways and to take advantage of different opportunities, it also generates conceptual dislocations whereby recognized authorship and the rules of the game seem to change without notice and success and failure seem capricious. The Garcías most acutely embody this ambivalence, not only because they are the most successful, but also because their work aesthetically deviates from the established genre of Oaxacan woodcarving. As I have discussed elsewhere, their success has been largely built upon the intentional development of an aesthetic repertoire in the direction of 'indigenous art.' In particular, they draw on American and Canadian aesthetics of indigeneity (colours, styles and forms) while symbolically connecting their work and themselves to a reified, even romantic, notion of 'Zapotec culture' (cf. Wood 2008: 105-114). This has allowed them to simultaneously tap into the aesthetic imaginaries that adhere to nationally-held notions of artesanías by Mexican audiences, and Canadian and American expectations of indigenous art (Cant forthcoming).

The tension between perceived collective culture and a desire for individual authorship is a common feature of 'cultural assets'; commodities like Oaxacan woodcarvings that are simultaneously claimed to be marketable, and yet have special cultural value for communities of producers and the nation-states that promote and seek to protect them. Crucially, for something to work as a cultural asset, it must not only be embedded in local expressions of tradition or culture, but must be to some degree enclosable, referring to the possibility of limiting production or trade only to recognized 'insiders' (Colloredo-Mansfeld 2011: 54-58). Enclosure is the ultimate aim of collective forms of IP such as the Oaxacan woodcarvings' 
collective trademark. However, the use of intellectual property frameworks to respond to the industrial replicas is problematic, since artisans hold different expectations about the rights of authors than those enshrined in IP principles and legislation. What the artisans' expectations about the collective trademark suggest is that their discourses of IP articulate anxieties primarily about relations between local producers themselves, who have an uneven ability to master the art world's aesthetic expectations, and that they are conscious that the industry is a recent and epistemologically unstable regime of value.

\section{Intellectual Property and 'InSpiriter' Industrial Replicas}

Intellectual property has become a great concern for actors and analysts concerned with the economic, social and legal consequences of globalization and neoliberal transformation in recent decades. The laws and language of intellectual and cultural property are globally extended through international bodies such as the World Trade Organization (WTO) and the United Nations, who use carrot-and-stick approaches like the Agreement on Trade Related Aspects of Intellectual Property (TRIPs) to encourage national governments to enact strong IP legislation (Bowen 2010; May and Sell 2006: 176-194). National governments have responded to this pressure by passing stricter IP laws and encouraging individuals and companies to register their work through patents and trademarks. With encouragement from the UN's World Intellectual Property Organization (WIPO), many nations have also sought to extend protection to artistic, expressive and cultural activities, which have become enshrined in international parlance as 'traditional knowledge' and 'traditional cultural expressions' (Aragon 2014; May and Sell 2006: 194-198, cf. WIPO 2004: 1-3). Not coincidentally, these attempts have come at a moment where there is a new emphasis in both development and 
business circles on the 'knowledge economy' and the 'information society,' key concepts promoted by international development institutions (Chan 2011: 91).

Despite apparent political differences, successive Mexican governments have increasingly consolidated IP in the context of larger political and economic change. In 1991, President Salinas signed the Law of Industrial Property, aligning Mexico with the requirements of the North American Free Trade Agreement, and in 1997, President Zedillo augmented this law by criminalizing certain copyright violations and by establishing two federal agencies responsible for enforcement and regulation: the National Copyright Institute and the Mexican Institute for Industrial Property (IMPI) (Smith 1998). Since 2000, the governments of both Fox and Calderón have further strengthened IP enforcement, partially by positioning it as a weapon against organized crime, since 'pirated' goods are increasingly alleged to fund drug cartels and other violent criminal organizations (Aguiar 2010). The Mexican state also currently directs a tremendous amount of resources towards putting IP into practice, and often works directly with the WIPO to educate cultural producers about the benefits of registering their work. Since 2004, twenty four different collective trademark programs have been established for Mexican artisanal products, like guitars and embroidered textiles from Guerrero, and Puebla's Talavera pottery (FONART 2012; IMPI 2009). In San Martín, artisans are also urged in government training sessions to register their individual workshops as private companies, with formally established trademarks. Although only a few artisans have taken the steps to do so, the language of intellectual property is now commonplace among producers. One artisan often told me that he was very happy since registering his company, as it will allow him to pass on his styles and rights to his children. He also saw his personal registered trademark as a tool through which he could discourage his 
neighbours from copying his styles, as this was a point emphasized by the government instructor.

Through these processes, IP has become entwined with the long-standing and pervasive ideologies of Mexican national patrimony. Public and media articulations of heritage in Mexico are now frequently expressed in the idiom of IP, often resulting in the relocation of formerly public spaces and objects to the commercializable sphere (Breglia 2006:31-35; Colloredo-Mansfeld 2011; Hayden 2003:87-90; Scher 2010). By the time the InSpiriter industrial replicas were discovered in Oaxaca, FONART and the Secretary of Economy had signed an agreement to actively register collective trademarks for Mexican artesanias (FONART 2012). The FONART and ARIPO representatives who worked with the artisans assured them that it would be easy to replicate these experiences, and that it was a worthwhile project. Over three meetings in 2008 and 2009, the collective trademark union's executive committee, made up of representatives from three villages, negotiated the terms by which individuals could join the union and use the trademark. Their stated objective was:

'to develop and register a collective trademark, denomination of origin, or any other national or international judicial form of commercial or intellectual protection, that has the objective of the protection, preservation, development and promotion of the techniques of [Oaxacan] woodcarvings' (UTPATO n.d.: 1, my translation). 
It is noteworthy that while many indigenous and minority groups frequently turn to IP in attempts to prevent the use of their culture by outsiders, the underlying reasoning of IP law stands in direct contradiction to the mobilization of rights in this way; IP was not developed to prevent the reproduction and circulation of images or ideas, but rather to guarantee that authors receive fair compensation for their use (Coombe 1998: 77-78; 86; 169; Brown 2003: 59-61; Merlan 2005). While the logics of IP do not readily provide the protection indigenous and minority groups seek, as Rosemary Coombe wryly observes, property-oriented claims are often more persuasive to the public and judiciaries than assertions of cultural or emotional injury, often making IP seem the more pragmatic choice (1998:174-207).

Notwithstanding the conceptual complications involved in trying to trademark culture, the InSpiriter industrial replicas are troublesome even if one takes a favourable perspective on the possibilities of IP protection, and it is worth noting the legal and practical difficulties the collective trademark faced when responding to the InSpiriter replicas. ${ }^{8}$ Collective trademarks are not intended to protect the content of works. Instead, they are arranged in order to identify products as the work of a member of a particular organization, which ostensibly guarantees certain levels of quality, geographical provenance, or other characteristics determined by the organization itself. What is protected is the use of the trademark's sign, name or logo, not the intellectual or aesthetic content of the objects to which it pertains. Thus the value of a trademark is its power to 'persuade consumers to consume a particular iteration of something that might be more generally available' (Leach 2008: 337; cf. Coombe 1998: 169-170; Brown 2003: 55-59, 74-76). However, even if the Oaxacan woodcarvings were protected under the stronger IP frameworks, it is doubtful the InSpiriters would be considered a legal violation, as it is unlikely that consumers could confuse them with Oaxacan woodcarvings. While they visually appear the same as the woodcarvings that served as their prototypes, there are 
significant material and marketing differences between the resin figures and the carvings, which underscore Antonio's bewilderment about the artisans' reaction, and render the collective trademark relatively impotent. ${ }^{9}$

Oaxacan woodcarvings are produced from copal, a softwood common to the arid regions of southern Mexico. Although it is moist and pliable when freshly cut, copal is brittle and extremely lightweight when dry giving the woodcarvings a distinctively delicate, hollowlike quality. The texture of copal also makes it ideal for carving, and artisans can produce both crisp clean edges and curved and flat surfaces. Once dry, the wood can be sanded to a very smooth finish that provides an ideal surface for the delicate application of paint; smoothness in carving and painting are valued as indicators of quality by both artisans and buyers alike. In contrast, the InSpiriters are made from an industrial polyresin compound that can be cast into moulds, which in this case were produced from the original woodcarvings that 'El Americano' purchased in 2006. The figures are surprisingly heavy and have a waxy, synthetic texture to them and as their design details are cast during the pouring of the resin, the decorative patterns feel raised on the surface, giving texture to each piece.

There are also significant differences in how and to whom the objects are marketed. The InSpiriters were produced by an Arizona-based company and sold directly to customers via an English language website and through other online retailers and shops. Nowhere on the website or their accompanying leaflet do they claim to be Oaxacan or even Mexican at all. They also do not explicitly claim to be indigenous or ethnic art, but instead rely on a generalized Native American aesthetic. InSpiriters are sold to two distinct but overlapping groups of consumers: North American New Age spiritualists and purchasers of what we may 
term 'giftware', industrially produced objects sold in gift and greeting card shops. Drawing on New Age interpretations of Native American spirituality, the website indicates each of the five InSpiriter animals carry special attributes that can be matched to the customer's personality and spiritual needs (Sterling and Camille Inc. 2009). They are sold through New Age and giftware websites and even received a 'best of show' recommendation from New Age Retailer Magazine (Haller and Group 2007:116-117). ${ }^{10}$

Despite the fact that the media and everyday explanations of the replicas argued that they threatened Oaxacan livelihoods and culture, these material and marketing differences between the Inspiriters and Oaxacan woodcarvings show that the copies posed no immediate threat to the cultural or economic wellbeing of Oaxacan artisans, and were unanswerable from the perspective of IP. In the final section of the paper, I return to my earlier suggestion that the InSpiriters provoked reaction from the artisans not because of the direct threat they posed, but because they exposed particular local ambiguities about authorship, and the desirability of Oaxacan woodcarvings.

\section{Aura, or the Allure of Art and Intellectual Property}

Despite the fact that the collective trademark mobilized discourses of IP as a way to address the InSpiriters, in fact this case offers a good example of what Mario Biagioli has identified as a frequent problem in common sense understandings of intellectual property: that plagiarism is often confused with copyright violation (2014: 66).${ }^{11}$ Biagioli argues that the reason why such cases provoke strong emotional reactions is plagiarism not only involves the 
unauthorized copying of a work ('piracy'), but also the displacement or denial of authorship. In examining the intimate conceptual connections between Western ideologies of authorship and parenthood, he argues:

'Copyright's notion of copy and plagiarism's notion of appropriation are significantly different, and not only because the former concerns objects while the latter focuses on relations. The difference may in fact be traceable to the specific location where the plagiarist inserts himself in the chain of authorial agency. Piracy operates downstream, affecting the production, circulation and sale of some copies of the work. Instead, because the author is construed as the origin of the work, the name swap performed by the plagiarist has the effect of appropriating the whole work...it is the scale of the appropriation resulting from the name swap that makes plagiarism feel 'personal': not so much the symbolic affront of seeing your name erased and substituted with that of somebody else, but the fact that, through that simple elision, you have indeed lost your whole work' (2014: 69-70).

Biagioli focuses on the author's affective experience of erasure and how acts of plagiarism fundamentally call into question the expected relationship between author and work over time; where IP concerns itself with ownership, plagiarism addresses authorship. However, as 'cultural objects,' Oaxacan woodcarvings are not necessarily linked by straightforward connections of single-author to single-work, and I suggest that the real danger the InSpiriters posed was not erasure so much as that they threatened to further reveal the inconsistent and unstable nature of the relationship between authorship and how woodcarvings are rendered authoritative in the first place. This touched a nerve for the 
woodcarvings' makers, and caused them to seek clarification via the already-institutionalized rules apparently offered by IP. In fact, apart from the general statement quoted above (p.15), the collective trademark's rules of use and other guidelines had nothing to say about intellectual property at all. Although the collective trademark presents artisans as if they are a single group with similar interests and goals, its details instead reveal a desire to create a uniformity of practice amongst artisans. The rules of the collective trademark not only serve as a way to define who should produce Oaxacan woodcarvings, but also how they should be produced. Instead of addressing the threat of replicas, the artisans who organized the collective trademark were more concerned with woodcarving production in Oaxaca.

The collective trademark's regulations begin by delimiting which Oaxacans have the right to produce carvings, stating that only artisans of legal age of majority from eleven designated communities are eligible to join the union. The list includes communities that are not particularly known for woodcarving production, but where families have occasionally made woodcarvings for sale. Julia Flores, San Martín's executive committee representative, explained to me that this clause was included because while they did not want to exclude anyone who has already begun to make carvings, they did not want 'any old Oaxacan to claim rights to our livelihoods.' Further, the regulations describe in detail acceptable materials, tools, and processes of production for making Oaxacan woodcarvings. There was also debate about whether all artisans from designated communities should be allowed to join the union, as it is well known that some, especially those in the lower-end of the market, often purchase unpainted carvings to finish and sell on as their own. Some believed that the collective trademark should only protect 'true' artisans who entirely produced the carvings themselves. 
These delineations of how and by whom authorized woodcarvings should be made are attempts at 'enclosure' through what Lorraine Aragon calls 'sequestering strategies', referring to the combination of secrecy and legal tools used by minority groups to protect themselves from outsiders who do not share their culture (2011:71-73). In this case, however, the sequestering strategies are instead focused on preventing other Oaxacans from making Oaxacan woodcarvings, rather than taking steps to halt illegitimate versions made by foreigners. Instead of preventing cultural appropriation by outsiders, the collective trademark actually creates boundaries between otherwise similar people (i.e. by distinguishing 'true artisans' from other Oaxacans), demarcating who can legitimately produce woodcarvings and who cannot. In order to understand why these practices of boundary-making are important, we must consider uncertainties about the connection between authorship, authority and desirability in the markets in which artisans work.

As described above, Oaxacan woodcarvings are produced within potent local and national discourses of art, craft, tradition and heritage. However, what purely culturaleconomic analyses of craft often elide is that the artistic authority and allure of specific works of art cannot be wholly understood by reference to tradition or market expectations. Some viewers and consumers of Oaxacan woodcarvings are often not as concerned with learning about the cultural intentions of artisans as they are with their own experiences of how the carvings embody certain feelings or perceptions. For example, one Mexican American visitor saw the purchase of an expensive carving as the reestablishment of a physical connection to her Mexican roots which she felt she had lost, while an Anglo-American collector saw his 'discovery' of an older piece in San Martín as evidence of his own identity as an ethnic art connoisseur and a cosmopolitan and well-travelled person (cf. Steiner 1995). This suggests that in order to understand the authority and desirability of art objects, we must account for 
their intersubjective nature, which can be theorized using Benjamin's concept of the 'aura' of works of art. Benjamin's aura is useful for thinking through the peculiar allure of both art objects and intellectual property, since the concept captures the affective and ideological dimensions of both.

Despite the uncertainties that have surrounded Benjamin's aura as an analytical concept (A. Benjamin 1986; Hansen 2008), I suggest that it can be usefully redeployed for the anthropological study of art, as it allows us to simultaneously pay attention to the creation of artistic authority, art's affective allure, and the contexts in which art is encountered (Cant 2012, forthcoming; cf. Steiner 1999; Pinney 2002; 2004:189-191). Benjamin ambiguously describes aura as 'genuineness' (W. Benjamin 2008: 5); 'singularity' (p. 10); or 'the here and now of the work of art' (p. 7); part of what gives art objects their power is that they are unique and therefore locatable in specific places through time (p. 10). ${ }^{12}$ But 'singularity' does not fully contain Benjamin's vision, for the aura is also art's inexplicable allure or desirability; what Alfred Gell calls 'enchantment', which prevents the viewer from completely comprehending, and therefore resolving the object (Gell 1998: 68-83). Gell famously reads this enchantment as a consequence of the viewer's subconscious inference ('abduction') of the intentionality and agency of the artist, which she experiences as the agency of the artwork itself (1998: 14-16; 23-24). However, from the perspective of my research, this model is problematic, as it does not reflect the potential power of the viewer within the encounter, and cannot account for the fact that artists' desires for their artworks often differ from their actual reception. Agency not only occurs as objects are produced and sent out into the world, but also materializes in a variety of ways as objects are 'read' by different viewers (Cant 2012). Thus, the authority or desirability of an artwork should not be understood as a given quality, but rather as a manifestation of the encounter between artist, object and viewer. It is therefore 
unstable and relational in character, and contingent on 'acts of reading and interpretation,' characteristics insinuated by Benjamin's aura (Hansen 2008: 359).

Focusing attention on the 'reading' of art objects necessarily raises issues of differential power in the ability to describe, classify and consume, and readings may not always be stable or consistent between different viewers or indeed different viewings. But it also raises the issue about the multiple factors that can influence these readings; they are necessarily conditioned by the contexts in which art is encountered; by the cultural, institutional or semantic frames in which it is presented; and by the motivating desires behind the attention given to the object by the viewer (cf. Price 1989; Errington 1998). One consequence of these acts of reading is that differences amongst viewer-consumers are more meaningful than they might at first appear. Although San Martín's artisans seem to be competing within the same field, not everyone has equal access to knowledge about different kinds of consumers. For example, the Garcías have benefitted from their long-standing friendships with particular dealers, collectors, and officials, who facilitate travel throughout Mexico and the United States. These journeys have allowed them insight into the aesthetic expectations of consumers of indigenous art, which they have actively incorporated into their own work. As they showed their work at increasingly important museums and up-market galleries, they also interacted with different kinds of artists and experts, exposing them to specialist discourses on skill, quality, aesthetics and history, thereby providing the language and the means through which to calibrate their work to the desires of wealthier consumers. In this way, the Garcías have enhanced the auratic authority and allure of their own work; their pieces appear more genuine and desirable than those of their competitors precisely because they fulfil connoisseurs' already-existing expectations of what ethnic art should be. 
While this situation is clearly beneficial to the Garcías, their success has generated a large amount of suspicion and anxiety in San Martín. It is widely known that their work commands much higher prices than others can attain, and their success was somewhat bewildering to some of their neighbours. Other artisans were aware of their relationships with gatekeepers, but were uncertain about what benefits they provided, and they only had vague ideas about how the Garcías' work and presentation diverged from their own. One artisan admitted that he went to the regional museum of popular art to look in more detail at pieces by successful families in order to, as he put it, 'steal their inspirations,' and he began producing what were essentially copies of the Garcías' work. He justified this by claiming that that they were selfishly using 'everyone's culture of woodcarving' for their own benefit, a sentiment that was expressed by other artisans in similar situations. Thus, even before the appearance of the InSpiriter figures, the linkages between culture, authorship and desirability in the Oaxacan woodcarving market were already ambiguous. For the majority of the Garcías' neighbours, the truth about the power of their woodcarvings is uncertain, and this provides part of the answer to Antonio's question: these artisans are concerned about the production of industrial copies since they cannot be sure about what is actually driving tourists' desires for their work, and therefore they also cannot be sure that the resin copies might not be able to meet these desires as well.

Given this, we might expect that successful artisans like the Garcías would be less concerned about the factory copies, since they seem to have learned the secret of their own work's desirability. Yet, the Garcías were in fact a major force in the initial formation of the collective trademark union. Their enthusiasm for the program becomes intelligible when considered in terms of the energy and time they have invested in constructing the fragile aura and aesthetics of ethnic art around their woodcarvings; they are under no illusions that the 
'ethnic art' discourses that they situate their work within might be right - that the aura of their work derives naturally from authentic indigenous identities in the Mexican countryside. Instead, they know that they have cultivated this aura through hard work and knowledge gleaned from other people and contexts far removed from San Martín, and that there is nothing stopping others from constructing auras around similar objects in the same way. In a conversation, Miguel admitted to me that he was worried because, as he put it, 'the InSpiriters have even stolen my selling style; this American has learned my moves.' The Garcías also know that the ethnic and tourist art markets, despite their apparent desires for authenticity, are highly susceptible to market pressures like costs of labour. For example, they know Zapotec weavers who have produced Navajo blanket designs at a fraction of the cost to sell in the United States (see Stephen 2005: 189-194; Wood 2008: 88-95). Thus the resin factory copies raise the spectre that their own designs, which are not especially unique within the context of Mexican popular art, could move out of San Martín to another sufficiently authentic location.

The appeal to IP for their designs, then, is precisely that - an attempt to protect the designs from use by other people, but specifically from other people who may also learn how to construct auratic power in the Mexican context, who could make products equally desirable to the same consumers who currently purchase Oaxacan woodcarvings from San Martín. This anxiety helps to explain the significant attention paid by artisans to the formalization of rules surrounding production processes and which Oaxacans have the right to produce woodcarvings. Given the fact that they were invented by a single person who was not related to anyone from San Martín, it is clear to them that the ability to produce both the carvings and the auras that surround them could easily be adopted by anyone living in the state of Oaxaca, as the aesthetics and the genre are connected to the region, and not to any specific community, culture or family. 


\section{Conclusion}

It is not immediately clear how the InSpiriters threaten the security of Oaxacan artisans in the tourist and ethnic art markets in which they work. For the tourists and collectors who are their primary consumers, the desirability of woodcarvings seem secure by their emplacement in what appear to be authentic household workshops, located in small rural communities like San Martín Tilcajete. The InSpiriter figures, in contrast, are not produced under these conditions, nor do they claim to be. Instead, they are directed towards an entirely different market in which they are desired for their reference to a generalized Native American spirituality. Despite this, the factory copies generated a large amount of anxiety amongst the artisans who produce them, and I have shown that this anxiety was due to the fact that the InSpiriters seemed to reveal the inconsistent and unstable nature of the aesthetic processes that take place in the production and marketing of Oaxacan woodcarvings. For many, the appearance of the InSpiriters touched a nerve about the fact that although consumers claim their work's appeal is due to its authentic production in San Martín, not everyone seems capable of producing equally desirable and authoritative carvings.

While the view from outside of San Martín may see the woodcarvings as more or less homogenous cultural artefacts, from the artisans' own perspective woodcarvings are heterogeneous aesthetic projects whose successes vary greatly, which generates concerns about how Oaxacan woodcarvings should be legitimately produced. These anxieties are addressed through the idiom of intellectual property because it appears to work as a 'place of condensation' where rules and boundaries can be set, and the logics of markets can be clarified; artisans' claims to IP were much more about Oaxacan production than the actions of foreign replica-makers. The development of the collective trademark seemed to offer a chance 
both to make sense of and to stabilize the economic and social processes in which they work, and itself seemed to generate an aura of possibility and hope for the future.

While this case is informative about the disjuncture between the formal intentions of IP and local appropriations of its discourses, it also is revealing about disjunctures in the organizing logics of ethnic art markets that exist in larger structures of neoliberal multiculturalism. When the relationship between people and culture becomes one of ownership within regimes in which property is expected to a circulating commodity, culture and cultural expressions cannot easily remain under the control of those to whom they apparently should belong. While these fault lines have frequently been beneficial for those artisans who have learned to add value to their work by aesthetically enhancing their own pieces' desirability, they also appear threatening to these same individuals because they suggest that the auras which they have worked so hard to construct around their work can easily be replicated elsewhere, assigned to copies, or even objects that just approximate their art.

In San Martín Tilcajete, the InSpiriters became a symbolic surrogate onto which anxieties about the genuineness of Oaxacan woodcarvings could be projected. Although these anxieties are partially generated by the capricious nature of ethnic art and tourism markets, they are also substantially grounded in the artisans' own aesthetic practices through which woodcarvings are produced in the first place. By considering Antonio's question from the perspective of aesthetic production and change, rather than intellectual property per se, the details of these apprehensions can be teased out of more general analyses that lay the tensions of local production for global markets at the feet of debates about 'authenticity' and 'rights.' 
In the Oaxacan folktales that the local newspaper accounts seem to echo, the Devil always extracts more from the pact than the protagonist had intended. In this case, Oaxacan artisans are still not quite sure exactly what was signed away on those contracts, but whatever it was, it is clear that their hold upon it had always been uncertain.

\footnotetext{
${ }^{1}$ See Salanueva Camargo 2007.

${ }^{2}$ In 2004, ARIPO, Artesanías e Industrias Populares del Estado de Oaxaca (Craftwork and
} Popular Industries of the State of Oaxaca) - changed its name to Instituto Oaxaqueño de las Artesanías, however most people continue to call it ARIPO.

${ }^{3}$ During the 1990s gallery owners and the state appropriated the term 'alebrije' from the famous papier-mâché figures of Mexico City, in order to market the woodcarvings more widely. Oaxacan woodcarvings are now considered by many Mexicans to be part of the same genre as papier-mâché figures, although most artisans themselves insist on a distinction between the two forms (cf. Brulotte 2012:175, n.2).

${ }^{4}$ With the exceptions of Mendoza Ruíz and Jimenez, all personal names are pseudonyms.

${ }^{5}$ For detailed histories of Oaxacan woodcarving, see Brulotte 2012 and Chibnik 2003.

${ }^{6}$ Figure based on a survey conducted March to April, 2008.

${ }^{7}$ Usos y costumbres was sanctified under reforms to Oaxaca's constitution in 1995. I am not meaning to suggest that this system is truly egalitarian, but it was often cited as evidence of egalitarianism by my research participants. For critical analyses of usos y costumbres, see work by Alejandro Anaya Muñoz, Jorge Hernández Díaz and Todd Eisenstadt.

${ }^{8}$ The collective trademark also faced practical problems in its execution: gallery owners in Oaxaca City were either unaware of it or were misinformed about its function, and the union was not effectively linked with actors in the tourism or museum industries. 
${ }^{9}$ Hypothetically, if a legal challenge was to be raised, it would have to be made on behalf of the individuals whose carvings were used as prototypes (and therefore not extending to Oaxacan woodcarvings in general), or it would have establish that Oaxacan woodcarvings are a protectable Traditional Cultural Expression, which are limited to a particular people or territory (May and Sell 2006: 194-198). Given the relatively short history of Oaxacan woodcarving, and that it is not limited to a definable people or territory, it would struggle to fit WIPO definitions.

${ }^{10}$ At the time of writing, the InSpiriters website is no longer available. It appears that the company is no longer trading, although the figures can still be purchased through other sites. Attempts to contact the owner in 2009 and 2010 were unsuccessful.

${ }^{11} \mathrm{He}$ points out that even when IP expires and content moves into the public domain, authorship must still be recognized (2014: 79).

${ }^{12}$ I use the lesser-known translation by J.A. Underwood, as he translates the German 'echtheit' to 'authority' rather than 'authenticity' to side-step the impedimenta this term carries in anthropology. 


\section{Acknowledgements:}

The research for this paper was generously funded by the Emslie Horniman Fund of the Royal Anthropological Institute. I offer great thanks to Antonio for his unexpected and challenging question and to San Martín's artisans and their families. I also thank the JRAI's anonymous reviewers and Editor Matei Candea, as well as Barbara Bodenhorn, Tom Boylston, Matthew Engelke, Martin Holbraad, Jayne Howell, Walter Little, Andrew Sanchez, Lynn Stephen, and seminar participants at the LSE and Brunel University for their feedback on different versions of this work.

\section{Note on Contributor:}

Alanna Cant is a Postdoctoral Fellow in the Department of Social Anthropology at the University of Oslo. She has trained in anthropology, development studies and Latin American studies in Canada and the United Kingdom, where she completed her Ph.D. at the London School of Economics in 2012.

\section{References Cited:}

Alonso, A. M. 2004. Conforming Disconformity: "Mestizaje," Hybridity, and the Aesthetics of Mexican Nationalism. Cultural Anthropology 19, 459-490.

Aguiar, J.C. 2010. La Piratería Como Conflicto: Discursos Sobre La Propiedad Intelectual en México. Revista de Ciencias Sociales 38,143-156.

2013. Smugglers, Fayuqueros, Piratas: Transitory Commodities and Illegality in the Trade of Pirated CDs in Mexico. PoLAR: Political and Legal Anthropology Review 36, 249-265. 
Aragon, L. 2011.Where Commons Meet Commerce: Circulation and Sequestration Strategies in Indonesian Arts Economies. Anthropology of Work Review 32, 63-76.

2014. Law Versus Lore: Copyright and Conflicting Claims about Culture and Property in Indonesia. Anthropology Today 30, 15-19.

Benjamin, A. 1986. The Decline of Art: Benjamin's Aura. Oxford Art Journal 9, 30-35.

Benjamin, W. 2008. The Work of Art in the Age of Mechanical Reproduction (trans.) J.A. Underwood. London: Penguin Press.

Biagioli, M. 2014. Plagiarism, Kinship and Slavery. Theory Culture \& Society 31, 65-91

Bowen, S. 2010. Development from Within? The Potential for Geographical Indications in the Global South. The Journal of World Intellectual Property 13, 231-252.

Bowen, S. and M. S. Gaytán. 2012. The Paradox of Protection: National identity, Global Commodity Chains, and the Tequila Industry. Social Problems 59, 70-93.

Breglia, L. 2006. Monumental Ambivalence: The politics of heritage. Austin: University of Texas Press.

Brown, M. 2003. Who Owns Native Culture? Cambridge: Harvard University Press.

Brulotte, R. 2012. Between Art and Artifact: Archaeological Replicas and Cultural Production in Oaxaca, Mexico. Austin: University of Texas Press.

Cant, A. 2012. Practising Aesthetics: Artisanal production and politics in a woodcarving village in Oaxaca, Mexico. Doctoral dissertation, Department of Anthropology, London School of Economics. 
Forthcoming. The Art of Indigeneity: Aesthetics and Competition in Mexican Economies of Culture. Ethnos: Journal of Anthropology. Published online 30/06/2014.

Chan, A. S. 2011. Competitive Tradition: Intellectual Property and New Millennial Craft. Anthropology of Work Review 32, 90-102.

Chibnik, M. 2003. Crafting Tradition: The Making and Marketing of Oaxacan Woodcarvings. Austin: University of Texas Press.

Coleman, E. 2004. Aboriginal Art and Identity: Crossing the Borders of Law's Imagination. Journal of Political Philosophy 12, 20-40.

Colloredo-Mansfeld, R. 2011. Work, Cultural Resources, and Community Commodities in the Global Economy. Anthropology of Work Review 32, 51-62.

Comaroff, J. L. and J. Comaroff 2009. Ethnicity, Inc. Chicago: University of Chicago Press

Coombe, R. 1998. The Cultural Life of Intellectual Properties: Authorship, Appropriation, and the Law. Durham: Duke University Press.

Dent, A. (ed) 2013. Brand Neoliberalism. Special issue of Cultural Anthropology 28, 110-179.

Errington, S. 1998. The Death of Authentic Primitive Art and Other Tales of Progress. Berkeley: University of California Press.

FONART [Fondo Nacional para el Fomento de las Artesanías] 2012. Marcas Colectivas Artesanales. Mexico City: Secretaría de Desarrollo Social.

García Canclini, N. 1993. Transforming Modernity: Popular culture in Mexico (trans.) Lidia Lozano. Austin: University of Texas Press. 
1995. Hybrid Cultures: Strategies for Entering and Leaving Modernity. Minneanapolis: University of Minnesota Press.

2014. Imagined Globalization. Durham: Duke University Press.

Geismar, H. 2005. Copyright in Context: Carvings, Carvers, and Commodities in Vanuatu. American Ethnologist 32, 437-459.

Gershon, I. 2011. Neoliberal Agency. Current Anthropology 52(4): 537-555.

Gell, A.1998. Art and Agency: An Anthropological Theory. Oxford: Oxford University Press.

Hale, C. R. 2005. Neoliberal Multiculturalism. PoLAR: Political and Legal Anthropology Review

Haller, J. and L. Group 2007. Best of Show: Ten Fabulous Finds from INATS West. New Age Retailer Magazine, September/October, 116-118.

Handler, R. and W. Saxon 1988. Dyssimulation: Reflexivity, Narrative, and the Quest for Authenticity in 'Living History'. Cultural Anthropology 3, 242-260.

Hansen, M. B. 2008. Benjamin's Aura. Critical Inquiry 34, 336-375.

Hayden, C. 2003. When Nature Goes Public: The making and unmaking of bioprospecting in Mexico. Princeton: Princeton University Press.

Hirsch, E. 2010 Property and Persons: New Forms and Contests in the Era of Neoliberalism. Annual Review of Anthropology 39, 347-360. 
IMPI [Instituto Mexicano de la Propiedad Industrial] 2009. El Registro de Marcas Colectivas como Proyecto Estratégico de Integración, Promoción y Desarrollo del Sector Artesanal en México. Mexico City: IMPI.

Leach, J. 2008. An Anthropological Approach to Transactions Involving Names and Marks, Drawing on Melanesia. In Trade Marks and Brands: An Interdisciplinary Critique (eds.) L. Bently, J. Davis, and J. C. Ginsburg, 319-342. Cambridge: Cambridge University Press.

Lira Vásquez, C. 2009. La Identidad “Colonial” de Oaxaca. Una Invención de La Política Turística Y Patrimonial. In Ciudades Mexicanas Del Siglo XX: Siete Estudios Históricos (eds.) C. Lira Vásquez and A. Rodríguez Kuri. Mexico City: Colegio de Mexico, Universidad Autónoma Metropolitana Unidad, and Consejo Nacional de Ciencia y Tecnología.

Little, W. 2004. Mayas in the Marketplace: Tourism, Globalization, and Cultural Identity. Austin: University of Texas Press.

2008. Living Within the Mundo Maya Project: Strategies of Maya Handicrafts Vendors. Latin American Perspectives 35, 87-102.

López, R. A. 2010. Crafting Mexico: Intellectuals, Artisans and the State after the Revolution. Durham: Duke University Press.

Martín-Barbero, J. 2000. Transformations in the Map: Identities and Culture Industries. Latin American Perspectives 27, 27-48.

May, C. 2010. The Global Political Economy of Intellectual Property Rights: The New Enclosures. London: Routledge.

May, C. and S. K. Sell 2006. Intellectual Property Rights: A Critical History. Boulder: Lynne Rienner. 
Merlan, F. 2005. Indigenous Movements in Australia. Annual Reviews in Anthropology 34, 471-494.

Murphy, A. and A. Stepick 1991. Social Inequality in Oaxaca: A History of Resistance and Change. Philadelphia: Temple University Press.

Myers, F. 2005 Some Properties of Art and Culture: Ontologies of the Image and Economies of Exchange. In Materiality (ed.) D. Miller, 88-117. Durham: Duke University Press.

Newell, S. 2013. Brands as Masks: Public secrecy and the counterfeit in Côte d'Ivoire. Journal of the Royal Anthropological Institute 19, 138-154.

Novelo, V. 1976. Artesanías y Capitalismo En México. Mexico City: Instituto Nacional de Antropología e Historia.

Pinney, C. 2002. The Indian Work of Art in the Age of Mechanical Reproduction: Or, What Happens When Peasants 'Get Hold' of Images. In Media Worlds: Anthropology on New Terrain (eds.) F. Ginsburg and L. Abu-Lughod, 355-369. Berkeley: University of California Press.

Price, S. 1989. Primitive Art in Civilized Places. Chicago: University of Chicago Press

Salanueva Camargo, P. 2007. Alebrijes Clonados. Las Noticias de Oaxaca, November 2. Available at http://biodivmesoam.blogspot.com/2007/11/alebrijes-clonados.html. Accessed 12 February, 2009.

Scher, P. 2011. Heritage Tourism in the Caribbean: The Politics of Culture after Neoliberalism. Bulletin of Latin American Research 30(1): 7-20.

Smith, P. 1998. Ley Federal Del Derecho de Autor. Berkeley Technology Law Journal 13, 503-516. 
Steiner, C. B. 1995. The Art of the Trade: On the Creation of Value and Authenticity in the African Art Market. In The Traffic in Culture: Refiguring Art and Anthropology (eds) G. Marcus and F. Myers, 151-165. Berkeley: University of California Press.

1999. Authenticity, Repetition and the Aesthetics of Seriality: The Work of Tourist Art in the Age of Mechanical Reproduction. In Unpacking Culture: Art and Commodity in Colonial and Postcolonial Worlds (eds.) R. Phillips and C. Steiner, 87-103. Berkeley: University of California Press.

Stephen, L. 2005. Zapotec Women: Gender, Class, and Ethnicity in Globalized Oaxaca (2nd edition) Durham: Duke University Press.

2013. We Are the Face of Oaxaca: Testimony and Social Movements. Durham: Duke University Press

Sterling \& Camille Inc. 2009. InSpiriters. Website at www.sterlingandcamille.com. Accessed 15 September, 2010.

Strathern, M. 1999. Property, Substance and Effect. London: Athlone Press.

Tan, L. 2013. Intellectual Property Law and the Globalization of Indigenous Cultural Expressions: Maori Tattoo and the Whitmill versus Warner Bros. Case. Theory, Culture \& Society $30,61-81$.

Thomas, K. 2013. Brand "Piracy" and Postwar Statecraft in Guatemala. Cultural Anthropology 28,144-160.

UTPATO [Unión de Talladores Productores de Alebrijes Tonas de Oaxaca] n.d. Reglas de Uso de la Marca Colectiva 'Tallas de Madera Alebrijes Tonas de Oaxaca.' Unpublished document. 
Villaseñor Alonso, I. and E. Zolla Márquez 2012. Del Patrimonio Cultural Inmaterial O La Patrimonializacion de La Cultura. Cultura y Representaciones Sociales 6, 75-101.

WIPO [World Intellectual Property Organization] 2004. La Clave de la Propiedad Intelectual: Guía para pequeños y medianos exportadores. Geneva: WIPO

Wood, W. W. 2008. Made in Mexico: Zapotec Weavers and the Global Ethnic Art Market. Indianapolis: University of Indiana Press. 